Document downloaded from:

http://hdl.handle.net/10251/62778

This paper must be cited as:

Martí Selva, ML.; Puertas Medina, RM. (2015). The importance of export logistics and trade costs in emerging economies. Maritime Economics and Logistics. 1-19.

doi:10.1057/mel.2015.31.

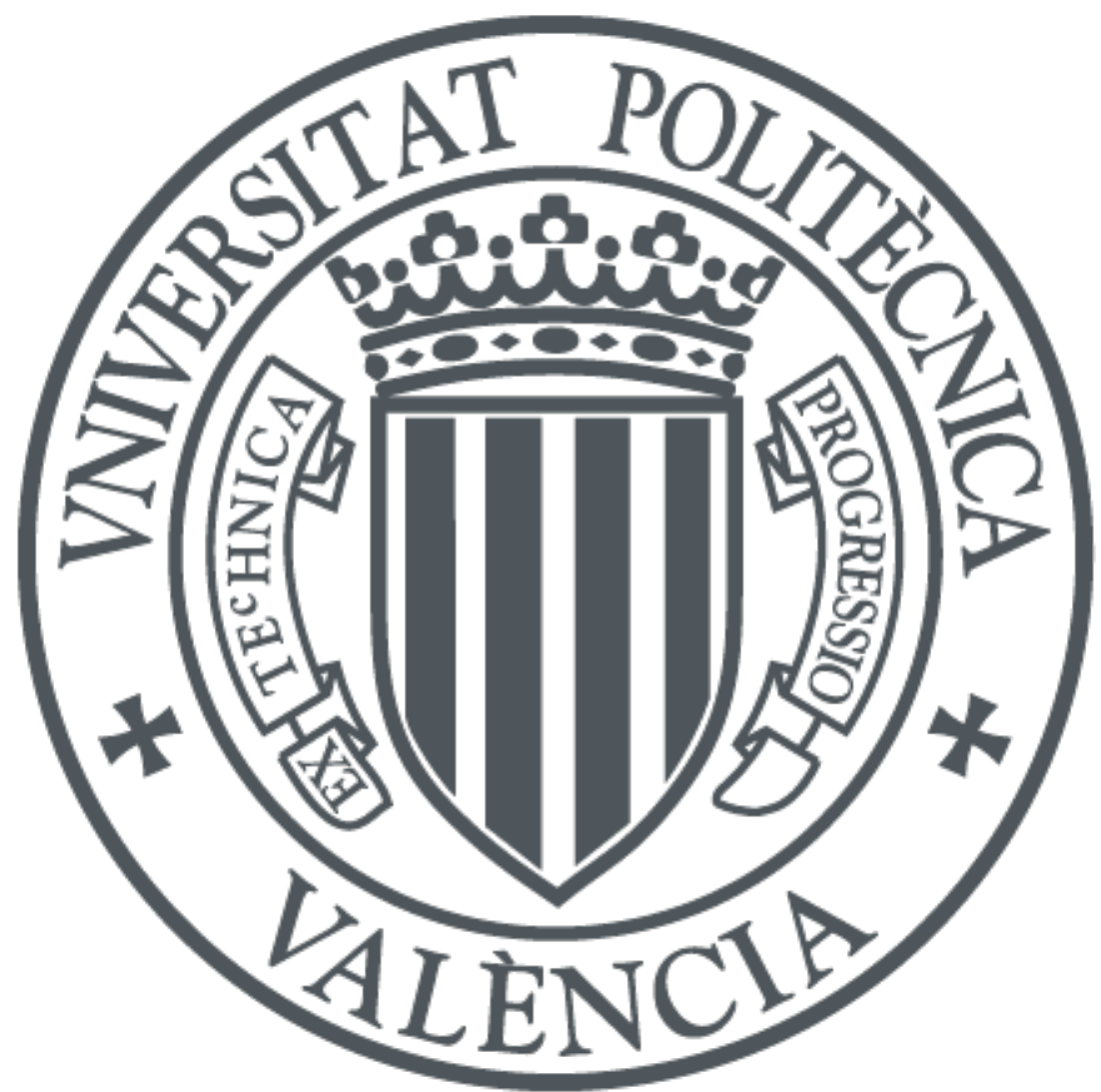

The final publication is available at

http://dx.doi.org/10.1057/mel.2015.31

Copyright Palgrave Macmillan

Additional Information 


\title{
The importance of export logistics and trade costs of emerging countries
}

\begin{abstract}
The aim of this paper is to analyse the importance of logistical performance in international trade and its influence on costs, focusing on the study of emerging countries with a maritime border. For this purpose, gravity models were used to determine the importance of logistics in these countries' exportations, taking as a representative variable the Logistics Performance Index and each of its components. Moreover, the equation of trade costs proposed by Novy (2013) was used to determine the importance of logistical performance. The results show that the analysed countries should continue to strive for improvement in logistical infrastructure not only to boost their trade but also to improve their competitiveness.
\end{abstract}

Keywords: Logistics Performance Index, Emerging countries, Trade cost, International trade

JEL: C59; F19; O57

\section{Introduction}

The high growth of international trade in recent years has not been free of obstacles. On one side, tariff and non-tariff barriers exist, which vary according to the sectors affected, and on the other, trade costs act as an impediment to trade and have been gaining importance and exerting influence on trade patterns in a significant way. The literature includes studies that have modelled these costs to examine their influence on export and import flows. Thus, Krugman (1991) emphasised their importance in economic geography models. Henderson et al. (2001) also underscored their role and projection on trade. In the same year, Limao and Venables (2001) analysed trade costs as a dependent variable based on geographical factors and infrastructure. Subsequently, Clark et al. (2004) investigated the determinants of US maritime costs, finding that port 
efficiency is a key factor. For their part, Wilmsmeier et al. (2006), regarding South American countries, have shown that port efficiency, infrastructure, private sector participation, and connectivity between ports are significant variables for costs. The empirical findings of Persson (2013) suggest that countries with large export transaction costs, will tend to export fewer goods.

At the sector level, Martínez-Zarzoso et al. (2003) investigated the factors influencing maritime transport costs applied to the ceramics sector in Spain. In the same line, Martínez-Zarzoso et al. (2008) focused on the determinants of maritime and ground transport cost differentiated for four sectors (agroindustry, ceramics, automotive, and machinery), concluding that its magnitude limits trade, especially in high value added sectors. More recently, Chen and Novy (2011) analysed trade costs between European countries by differentiating various economic sectors, contributing evidence regarding important factors such as distance, non-tariff measures, and initiatives of member countries. Miroudot et al. (2012) apply the same methodology to services trade. Nowadays, Bensassi et al (2015) investigate the determinants of maritime trade focusing in particular on the extent to which variations in trade-related costs between Asia and Europe help to explain the surge in Euro - Asian trade in eight of the most emblematic categories of products related to Asian success.

In the context of exports, the trade facilitators are linked to the determination of trade costs. According to Moïsé and Sorescu (2013), this concept refers to policies and measures focused on decreasing trade costs by improving efficiency in each link in the chain of international relations. These authors build, based on 97 variables, sixteen indicators of trade facilitators, including the Logistics Performance Index (LPI) published by the World Bank, to evaluate how certain types of progress may determine costs and increase trade volume. Specifically, improvements in available information, 
the simplification and automation of procedures, and customs transparency are among the key factors to be taken into account. Furthermore, the combination of their effects is greater than the simple sum of individual impacts, with the reduction of trade costs ranging from $15.5 \%$ to $13.3 \%$ depending on country income levels.

Other studies have use done sole indicator to estimate trade facilitation and ascertain its impact on exports (Dennis 2006 y Decreux and Fontagne 2006). Behar and Manners (2008) use the LPI published by the World Bank to explore the relationships that exist between bilateral exports and logistics. Some authors (Hoekman and Nicita, 2011, also Korinek and Sourdin, 2011) include the LPI using a gravity equation for exports as an indicator of trade costs, together with others such as Doing Business Costs, concluding that domestic costs are quantitatively important and that the LPI has the largest effect on trade.

Following this line of research, the aim of this article is to analyse the importance of logistical performance for international trade and its influence on costs, with a focus on emerging countries with a maritime border, grouped into five areas (Africa, Eastern Europe, The Far East, South America and the Middle East). The LPI is considered a good proxy of trade facilitation, although it does not cover the entire concept. Furthermore, in order to detect possible patterns in performance, we will use the econometric approach of gravity models traditionally applied in studies on international trade and perform different estimations depending on the geographical region the exporting country belongs. Second, the equation of trade costs proposed by Arvis et al (2013) will be used to determine the importance of logistical performance. This analysis allows establishing conclusions about what type of improvements will lead to cost reductions and, therefore, to greater international competitiveness. 
The analysis has been conducted for the years 2005 and 2008, also facilitating the detection of possible changes that can in turn reveal the existence of a behaviour pattern in these countries. The limitation of available information regarding certain variables has made it impossible to study subsequent years. However, the results may serve as a guide for these countries to verify whether efforts aimed at improving logistics have been fruitful or, to the contrary, if there are certain areas of vital importance where there should be more effort.

The paper is structured as follows. In section 2, LPI is described, along with the key trade costs in the empirical study. Section 3 includes a detailed explanation of the methodology, specifying the equations to be estimated and the sample used. In section 4, the obtained results are analysed through the application of the Heckman procedure and of ordinary least squares (OLS). Finally, in section 5, the main conclusions are summarised.

\section{Logistics Performance Index and trade costs}

The LPI, published by the World Bank (Arvis et al. 2007, 2010 and 2012), tries to measure the logistical performance of 150 countries (43 from Africa, 42 from Europe, 41 from Asia, 22 from South America, 5 from the Pacific, and 2 from North America). This measure is based on surveys given to logistics professionals from the countries (international freight agents and transport companies) to assess the predictability and reliability of specific aspects related to goods transport. Therefore, it is important to state that the index works on a qualitative base of respondents, as opposed to other indicators that are determined using real infrastructure data. The questionnaire consists of questions whose answers are qualitative and quantitative, focused on the following axes: 
- Customs: Measures agility clearance processes, in terms of speed, simplicity and predictability of formal issues conducted by customs control bodies.

- Infrastructure: Evaluates the quality of maritime, land, rail and air transport infrastructure. The perception held by respondents about this infrastructure is valuated in terms of the modes of transport together with storage and moving goods.

- International shipments: Measures the ease of negotiating competitive prices for sending.

- Logistics quality and competence: Indicates the quality of logistical services, such as transport operators or customs agents.

- Tracking and tracing: Measures the follow-up and location of shipments. Identifying the exact location and route followed by each good is relevant up to the moment of delivery to the final client. In this component, all agents of the good's supply chain are involved; therefore, traceability is the result of global action.

- Timeliness: Refers to the exact time of shipment delivery. It is important to consider this factor because due to the high degree of existing competition, not meeting the established times is unacceptable.

None of these areas alone can assure good logistics performance. The LPI synthesises all of this information, allowing comparisons between countries. Thus, the weighted average of these six components creates an index that reflects the perception of the logistics of a country. Its score can range from 1 (worst) to 5 points (best). In general, low-income countries, with little development or geographical impediments as far as market access goes, occupy the last places of the ranking (countries from Africa 
and Central Asia). However, it should be clarified that when trade has been a factor in accelerating their growth, logistical performance is also significantly better than in other locations with similar income levels (India and Vietnam, both low income, are ranked 46 and 53, respectively, in 2010).

The most developed countries are located in the upper spots of the ranking, although significant differences between countries with similar rankings can be observed. For example, China, categorised as a medium income country, was ranked 26 in 2010, while certain high income countries, such as oil producing countries, are located in lower positions (Saudi Arabia is ranked 37). Therefore, the income segment is not a determinant of the position obtained.

The analysed trade costs in the paper include all costs related to goods trade between two countries in a broad sense. The trade costs do not refer only to costs related to international trade and tariffs but also to other components that are relevant according to Anderson and van Wincoop (2003), such as language, currency, or complicated export or import procedures. Based on the estimated gravity model, Novy (2013) measured cost as a geometric mean of bilateral and international trade costs, underscoring how much more expensive international trade is in comparison with its national counterpart. Therefore, trade costs are defined as follows:

$$
\tau_{i j t} \stackrel{\text { def }}{=}\left(\frac{t_{i j t} t_{j i t}}{t_{i i t} t_{j j t}}\right)^{\frac{1}{2}}-1=\left(\frac{x_{i i t} x_{j j t}}{x_{i j t} x_{j i t}}\right)^{\frac{1}{2(\sigma-1)}}-1
$$

where

$\tau_{i j t}$ : Geometric mean of trade costs between country $\mathrm{i}$ and country $\mathrm{j}$ at time $\mathrm{t}$

$t_{\mathrm{ijt}}$ : Costs of international trade from country $i$ to country $\mathrm{j}$ at time $\mathrm{t}$

$t_{j i t}$ : Costs of international trade from country $j$ to country $i$ at time $t$

$t_{\text {iit }}$ : Costs of intra-national trade from country i at time $t$

$\mathrm{t}_{\mathrm{jjt}}$ : Costs of intra-national trade from country $\mathrm{j}$ at time $\mathrm{t}$

$\mathrm{x}_{\mathrm{ijj}}$ : Flow of international trade from country $\mathrm{i}$ to country $\mathrm{j}$ at time $\mathrm{t}$ 
$\mathrm{x}_{\mathrm{jit}}$ : Flow of international trade from country $\mathrm{j}$ to country $\mathrm{i}$ at time $\mathrm{t}$

$\mathrm{x}_{\mathrm{iit}}$ : Flow of intra-national trade from country $\mathrm{i}$ at time $\mathrm{t}$

$\mathrm{x}_{\mathrm{jj \textrm {j }}}$ : Flow of intra-national trade from country $\mathrm{j}$ at time $\mathrm{t}$

$\sigma$ : Specific substitution elasticity between goods (Novy considers that the substitution elasticity equals eight in all countries and years, which represents a mean value of conducted estimates).

The variable $\tau_{i j t}$ includes not only the international transport costs and tariffs but also a wide range of trade costs that hamper international trade (Duval and Utoktham, 2011). This value is an approximation that is more exact than estimations traditionally used in gravity models based on geographical distance, as it includes observable and non-observable factors. The tariff and non-tariff measures constitute one single component, as well as transport costs, behind the border barriers and costs linked to the provision of logistical services (Arvis et al. 2013). $\tau_{\mathrm{ijt}}$ is publicated by World Bank and it represents the dependent variable of our trade cost equation.

Empirical analysis is focused on a comparison among five groups of emerging countries with the characteristics of having a maritime border: Africa, Eastern Europe, the Far East, South America, and the Middle East, defined by the following countries.

- South America: Argentina, Brazil, Chile, Colombia, Costa Rica, Ecuador, El Salvador, Guatemala, Guyana, Honduras, Jamaica, Mexico, Panama, Peru, Uruguay, and Venezuela.

- Africa: Algeria, Benin, Cameroon, Egypt, Gabon, Gambia, Ghana, Kenya, Madagascar, Morocco, Mauritius, Mauritania, Namibia, Senegal, South Africa, Sudan, Togo, and Tunisia.

- The Middle East: Saudi Arabia, Cyprus, United Arab Emirates, Iran, Jordan, Oman, Pakistan, Qatar, Syria, Turkey, and Yemen. 
- The Far East: China, the Philippines, India, Indonesia, Malaysia, Sri Lanka, Thailand, and Vietnam.

- Eastern Europe: Russia, Poland, Romania, Bulgaria, Ukraine, Lithuania, Latvia, and Estonia. In this group, we include some countries that belong to the European Union; however, according to their level of logistical development, it is deemed fitting that they be included with other developing countries

In Figure 1, the mean trade costs in each of these areas for the two years analysed are presented.

Figure 1. Mean trade costs (\% of ad valorem equivalent)

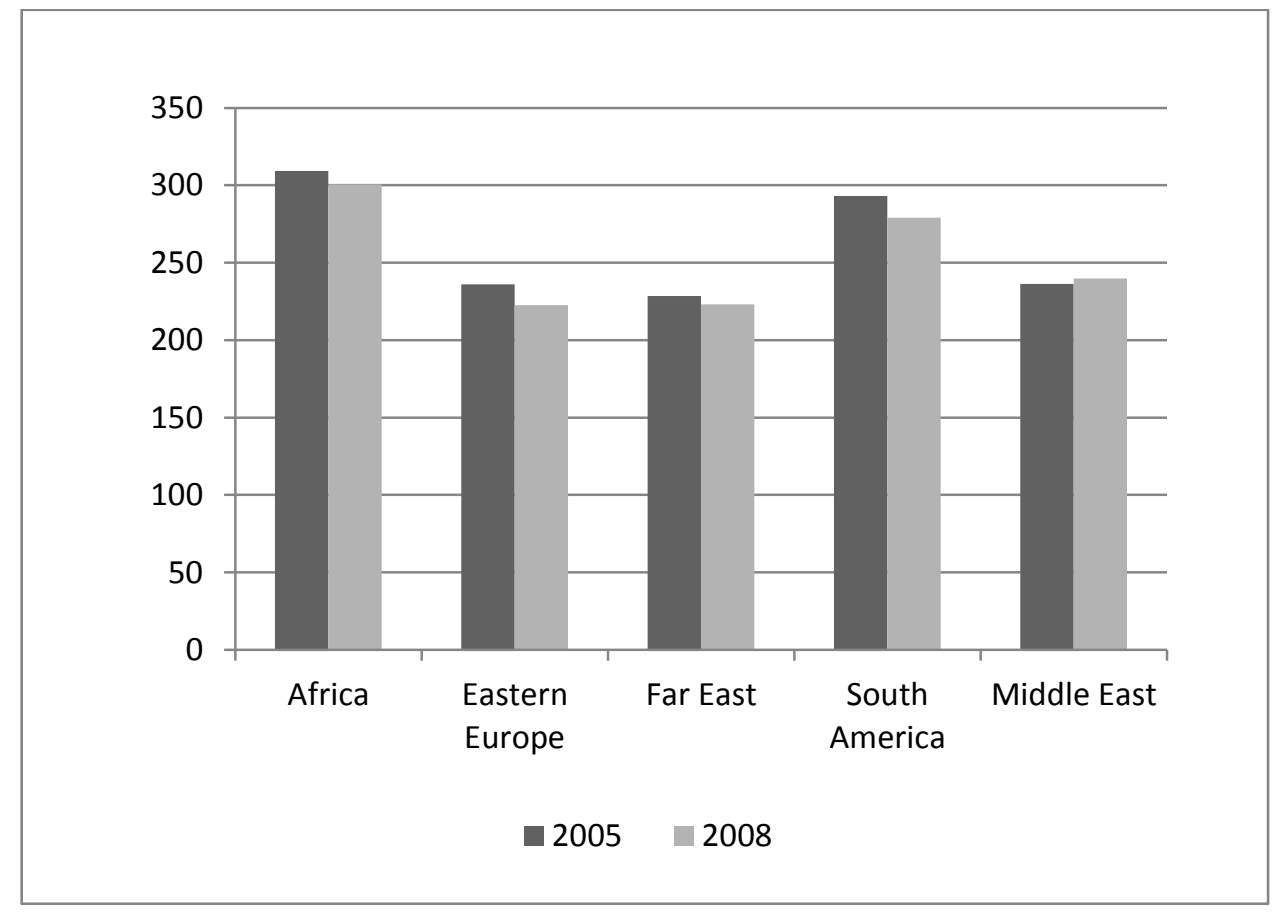

Source: Own elaboration. Data from ESCAP World Bank: International Trade Costs

African countries have the highest costs among emerging economies, reaching $300 \%$ ad valorem in 2005, followed by South American countries. Another important observation is the decrease of costs in nearly all areas in 2008, favouring international 
trade relations, which was especially prominent in Eastern Europe with a drop of 5.7\% and South America with $4.8 \%$, which is a consequence of a generalised lowering of tariffs and maximising other trade facilitator factors.

\section{Methodology: gravity equation, costs model, and sample}

The determinants of exports from emerging areas have usually been quantified by gravity models, which form a consolidated reference in the literature about bilateral trade between countries (Anderson, 1979; Bergstrand, 1985, 1989; Helpman and Krugman, 1985; Deardoff, 1995; Evenett and Keller, 1998; Anderson and van Wincoop, 2003; Martínez et al., 2012, among others).

Gravity equations in their most basic specification include explanatory variables based on income levels for the countries of origin and destination, their population, and geographical distance as proxy for transport costs, with their origin going back to Tinbergen (1962) and Pöyhönen (1963a,b). In this paper, both the LPI variable in the equation of trade as logistics proxy as well as theoretically socio-cultural variables that determine trade relations are included (e.g., sharing a language or border, having colonial ties). Its expression is as follows:

$\log \left(\mathrm{X}_{\mathrm{ijt}}\right)=\beta_{0}+\beta_{1} \log \left(\mathrm{D}_{\mathrm{ij}}\right)+\beta_{2} \log \left(\mathrm{Y}_{\mathrm{it}}\right)+\beta_{3} \log \left(\mathrm{Y}_{\mathrm{jt}}\right)+\beta_{4} \log \left(\mathrm{P}_{\mathrm{it}}\right)+\beta_{5} \log \left(\mathrm{P}_{\mathrm{jt}}\right)$

$+\beta_{6} \mathrm{LPI}_{\mathrm{it}}+\beta_{7} \mathrm{LPI}_{\mathrm{jt}}+\beta_{\mathrm{A}} \mathrm{W}+\mathrm{u}_{\mathrm{ij}}$

where,

$\mathrm{X}_{\mathrm{ijt}}$ : Quantity exported by country $\mathrm{i}$ to country $\mathrm{j}$ at time $\mathrm{t}$

$\mathrm{D}_{\mathrm{ij}}$ : Distance between country $\mathrm{i}$ and country $\mathrm{j}$

$Y_{\text {it }}$ : GDP nominal of country $i$ at time $t$

$\mathrm{Y}_{\mathrm{jt}}$ : GDP nominal of country $\mathrm{j}$ at time $\mathrm{t}$

$\mathrm{P}_{\mathrm{it}}$ : Population of country $\mathrm{i}$ at time $\mathrm{t}$

$\mathrm{P}_{\mathrm{jt}}$ : population of country $\mathrm{j}$ at time $\mathrm{t}$

LPI $_{\mathrm{it}}$ : Logistics Performance Index for country $i$ at time $t$

$\mathrm{LPI}_{\mathrm{j} t}$ : Logistics Performance Index for country $\mathrm{j}$ at time $\mathrm{t}$

W: Dummy variables: border (conting) official languages (c.off), second languages (c.ethno), have been ever colony (colony), have common colonizer after 1945 
(comcol), maintaining a colonial relationship after 1945 (col45), have been or being the same country (smctry)

$\mathrm{u}_{\mathrm{ij}}$ : Standard error

According to equation (2), export volume is a function of economic, geographic, demographic, and also logistic variables. In this proposal, the original hypothesis is that the included variables have a significant impact on trade, and the signs are coherent with the postulates of economic theory. Distance, as an indication of transport costs, is problematic when assumed to be independent of the mode of transport used and the capitals or economic centres of the country. The effect of distance between countries $\left(\beta_{1}\right)$ should be negative because closeness promotes more trade.

Theoretically, the GDP coefficients of both the exporter and importer $\left(\beta_{2}\right.$ and $\left.\beta_{3}\right)$ will be positive, and with more economic value, there is an expectation that exports and imports will be more significant. However, the population coefficient for the exporter $\left(\beta_{4}\right)$ can be positive or negative depending on whether the more populous country exports less due to an absorption effect of domestic production or exports more due to the predominance of technological and logistic variables associated with the level of economic development. In turn, the population coefficient of the importer $\left(\beta_{5}\right)$ also has an ambiguous sign for the same reasons that have been presented above.

According to the aim of the paper, the values of LPI for the exporter and importer are included in the gravity model, which will have associated coefficients $\left(\beta_{6}\right.$ and $\beta_{7}$ ) that represent the importance of trade facilitators in exports flows; a positive sign is expected in both cases. Lastly, the set of dummy variables represents the existing social and cultural similarities between the countries from the analysed geographical areas. 
The information on export, valued in dollars, has been taken from the Comtrade database (United Nations). This database is considered to be one of the most complete, as it has international trade statistics organised by products and countries starting from 1962. Regarding explanatory variables, distance between countries, expressed in kilometres, has been obtained from CEPII (Centre d'Etudes Prospectives et d'Informations Internationals), serving as a first approximation given the complexity of determining the location of production areas, which are often distributed throughout a given territory. The GDP data (expressed in dollars) and population have been obtained from the United Nations database. Finally, the set of dummy variables that characterise countries socially and culturally has also been obtained from CEPII.

Furthermore, the study has been particularised for each of the LPI components, facilitating the analysis of its influence on export flows and thus focusing more precisely on the conclusions. The existence of a strong correlation between the elements defining LPI makes it impractical to estimate a single equation with all of the components, which would lead to a situation of multicollinearity, providing erroneous results. Therefore, regressions have been estimated that are similar to equation (2), individually including each of the index components. As a result, the following equations have been defined:

$\log \left(X_{i j t}\right)=\beta_{0}+\beta_{1} \log \left(D_{i j}\right)+\beta_{2} \log \left(Y_{i t}\right)+\beta_{3} \log \left(Y_{j t}\right)+\beta_{4} \log \left(P_{i t}\right)+\beta_{5} \log \left(P_{j t}\right)$

$+\beta_{6} \log \left(\right.$ Customs $\left._{\mathrm{it}}\right)+\beta_{7} \log \left(\right.$ Customs $\left._{\mathrm{jt}}\right)+\beta_{\mathrm{A}} \mathrm{W}+\mathrm{u}_{\mathrm{ij}}$

$\log \left(X_{i j t}\right)=\beta_{0}+\beta_{1} \log \left(D_{i j}\right)+\beta_{2} \log \left(Y_{i t}\right)+\beta_{3} \log \left(Y_{j t}\right)+\beta_{4} \log \left(P_{i t}\right)+\beta_{5} \log \left(P_{j t}\right)$ $+\beta_{6} \log \left(\right.$ Infraestructure $\left._{i t}\right)+\beta_{7} \log \left(\right.$ Infraestructure $\left._{\mathrm{jt}}\right)+\beta_{\mathrm{A}} \mathrm{W}+\mathrm{u}_{\mathrm{ij}}$

$\log \left(X_{i j t}\right)=\beta_{0}+\beta_{1} \log \left(D_{i j}\right)+\beta_{2} \log \left(Y_{i t}\right)+\beta_{3} \log \left(Y_{j t}\right)+\beta_{4} \log \left(P_{i t}\right)+\beta_{5} \log \left(P_{j t}\right)$ $+\beta_{6} \log \left(\right.$ International shipment $\left._{i t}\right)+\beta_{7} \log \left(\right.$ International shipment $\left.\mathrm{j}_{\mathrm{t}}\right)+\beta_{\mathrm{A}} \mathrm{W}+\mathrm{u}_{\mathrm{ij}}$ 
$\log \left(X_{i j t}\right)=\beta_{0}+\beta_{1} \log \left(D_{i j}\right)+\beta_{2} \log \left(Y_{i t}\right)+\beta_{3} \log \left(Y_{j t}\right)+\beta_{4} \log \left(P_{i t}\right)+\beta_{5} \log \left(P_{j t}\right)$

$+\beta_{6} \log \left(\right.$ Competence $\left._{i t}\right)+\beta_{7} \log \left(\right.$ Competence $\left._{j \mathrm{t}}\right)+\beta_{\mathrm{A}} \mathrm{W}+\mathrm{u}_{\mathrm{ij}}$

$\log \left(X_{i j t}\right)=\beta_{0}+\beta_{1} \log \left(D_{i j}\right)+\beta_{2} \log \left(Y_{i t}\right)+\beta_{3} \log \left(Y_{j t}\right)+\beta_{4} \log \left(P_{i t}\right)+\beta_{5} \log \left(P_{j t}\right)$

$+\beta_{6} \log \left(\right.$ Tracking $\left._{\mathrm{it}}\right)+\beta_{7} \log \left(\right.$ Tracking $\left._{\mathrm{j}}\right)+\beta_{\mathrm{A}} \mathrm{W}+\mathrm{u}_{\mathrm{ij}}$

$\log \left(X_{i j t}\right)=\beta_{0}+\beta_{1} \log \left(D_{i j}\right)+\beta_{2} \log \left(Y_{i t}\right)+\beta_{3} \log \left(Y_{j t}\right)+\beta_{4} \log \left(P_{i t}\right)+\beta_{5} \log \left(P_{j t}\right)$

$+\beta_{6} \log \left(\right.$ Timeliness $\left._{\mathrm{it}}\right)+\beta_{7} \log \left(\right.$ Timeliness $\left._{\mathrm{jt}}\right)+\beta_{\mathrm{A}} \mathrm{W}+\mathrm{u}_{\mathrm{ij}}$

Initially, it was expected that each LPI component would present a positive coefficient, indicating that higher levels of these variables favour international trade. The comparison between results of the estimation will allow for the identification of which of these variables has a greater impact on trade flows from each geographical area and its evolution from 2005 to 2008.

An important aspect of estimating gravity equations is the treatment of flows that equal zero. Normally, they are not distributed randomly, and the literature warns of creating a selection bias in the sample if the gravity model is estimated by OLS, eliminating observations that lack exports. Given this problem, Heckman (1979) proposed the use of the Heckman procedure in two stages. The first step of this method consists of estimating a probit model to calculate the probability (given certain variables of interest that would determine this decision) that trade should exist between these two countries, obtaining the statistic known as the inverse Mills ratio, which captures the magnitude of this bias. Subsequently, the estimation of this ratio is incorporated into the original regression model to be added as one more regressor. In this way and using OLS, the significance of this coefficient will be obtained, indicating the magnitude of the bias that would be created if the non-existence of trade between these two given countries was not included. 
Secondly, and in line with Chen and Novy (2011) and Arvis et al. (2013), we defined an equation that allows us to explain the determinants of costs. Specifically, the expression is as follows:

$$
\begin{aligned}
& \log \left(\tau_{i j t}\right)=\beta_{0}+\beta_{1} \log \left(D_{i j}\right)+\beta_{2} \log \left(1+T_{i j t}\right)+\beta_{3} \log \left(E_{i j t}\right)+\beta_{4} \log \left(A I_{i j t}\right) \\
& +\beta_{5} \log \left(E C_{i j t}\right)+\beta_{6} \operatorname{LPI}_{i j t}+\beta_{A} W+u_{i j}
\end{aligned}
$$

where,

$\tau_{i j t}$ : Trade Cost between country $\mathrm{i}$ and country $\mathrm{j}$ at time $\mathrm{t}$

$D_{\mathrm{ij}}$ : Distance between country $\mathrm{i}$ and country $\mathrm{j}$

$\mathrm{T}_{\mathrm{ijt}}$ : Geometric average of unity plus the trade-weighted average effectively applied tariff applied to $i$ to j's exports and by $j$ to i's exports at time $t$

$\mathrm{ER}_{\mathrm{ijt}}$ : Geometric average of the official exchange rate (LCU per US\$, period average) of country $i$ and country $j$ at time $t$

$\mathrm{ACI}_{\mathrm{ijt}}$ : Geometric average of country i's and j's score on the Air Connectivity Index at time $\mathrm{t}$

$\mathrm{EC}_{\mathrm{ijt}}$ : Geometric average of the cost of starting a business in country $\mathrm{i}$ and country $\mathrm{j}$

$\mathrm{LPI}_{\mathrm{ij}}$ : Geometric average of country i's and j's score on the Logistics Performance Index at time $\mathrm{t}$

W: Dummy variables (common border, official language, second language, colony, same country, same RTA)

$\mathrm{u}_{\mathrm{ij}}$ Standard error

Trade costs are expressed as a percentage of equivalent ad valorem, obtained from the World Bank database (ESCAP World Bank: International Trade Costs). These values are explained by variables such as distance, LPI, and other dummy variables that are all common to the gravity model and explained above; the distance coefficient is expected to be positive while the signs of the other variables ones must be negatives. Furthermore, in this model, we add other more specific factors such as tariffs (expecting positive sign) and an air connectivity index (expecting negative sign), also from the World Bank, as well as the costs of entry (expecting positive sign) obtained from Doing Business. The exchange rate (expecting positive sign) is taken from the World Development Indicators. Considering that trade costs are a geometrical mean, the rest of the independent bidirectional variables have been transformed, taking the geometrical 
mean for both directions. In this way, only one direction for each bilateral par of trade relations has been maintained.

Both estimated gravity models and the trade costs equation have been defined for the five geographical areas. The set of importers consists of 145 countries whose LPI for 2005 and 2008 was published by the World Bank (Countries that do not provide information on LPI have been eliminated ).

In summary, the study mainly focuses on trade flows for maritime transport for emerging countries with a maritime border. In this group, the analysis of the importance of trade facilitators and cost becomes a key issue for growth, which can be conditioned by the adequate development of these variables.

\section{Results}

The analysis of trade relation determinants has been conducted using an estimation of equation (2). We have considered LPI as an indicator that is important for trade facilitators of export flows for 2005 and 2008 (Table 1). 
Table 1. Coefficients of the Gravity estimation in 2005 and 2008

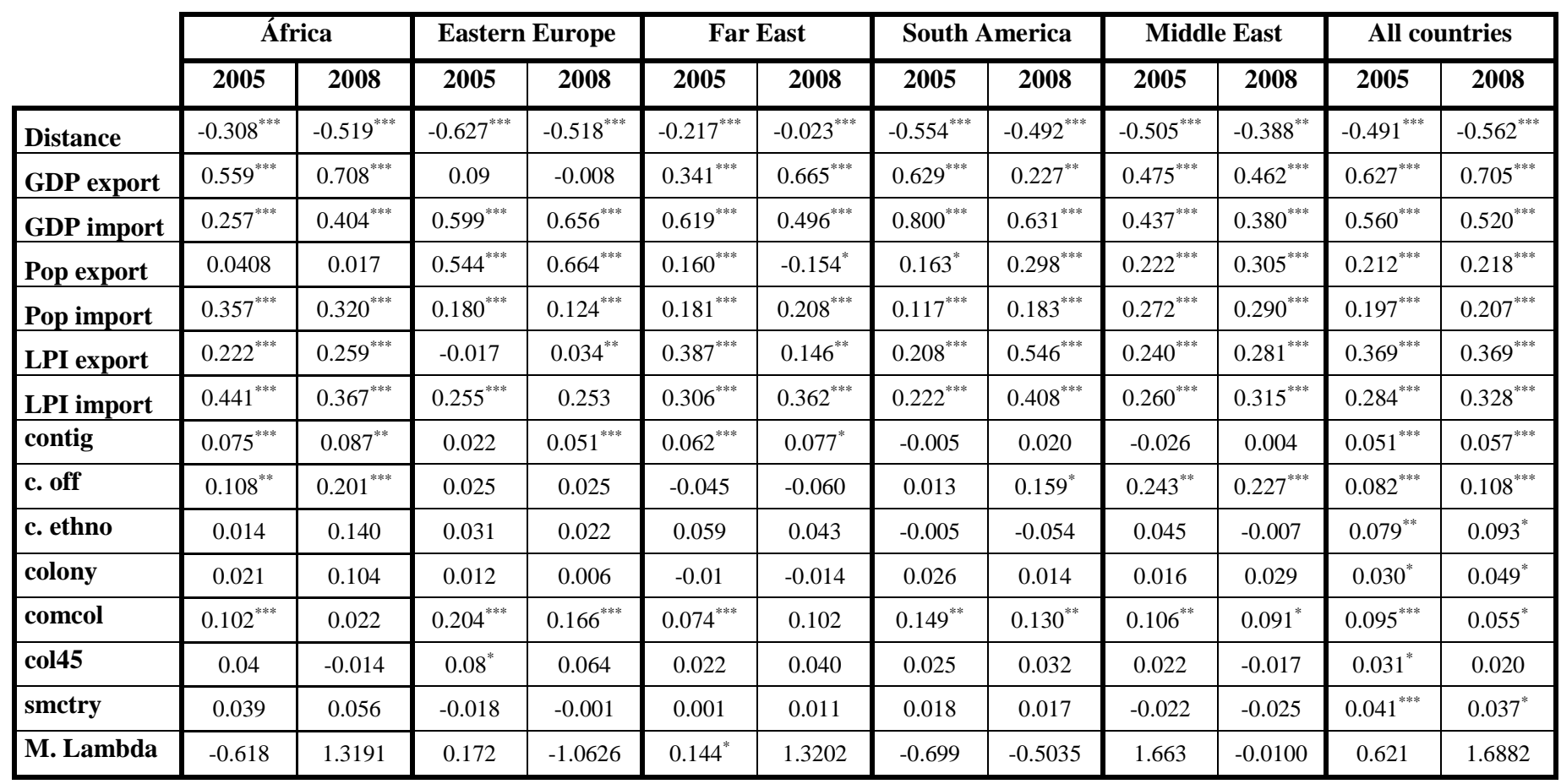

Dependent variable: Exportations

Note: $*, * *$ and $* * *$ denote test statistical significance at the $10 \%, 5 \%$ and $1 \%$ levels, respectively.

Source: Own elaboration

The results show the standardised coefficients for each of the analysed areas, i.e., the change in standard deviation of the dependent variable when modifying a unit of standard deviation of each of the explanatory variables. In this way, it is possible to compare the betas between one set of variables and another even though they are measured in different units, thus establishing an order of importance.

Distance is significant in all cases, presenting a negative sign according to the postulate that the greater the distance, the lower the volume of trade relations between countries. Mean elasticity for all countries is approximately 0.5 in 2005 and below that value for 2008, with exporters from Eastern Europe being most affected by this factor. Income indicators such as exporter and importer GDP present significant coefficients with positive signs (except for the case of Eastern Europe), implying that the higher their income level, the more countries engage in trade. At the global level, exporter 
GDP is the most influential variable on trade flows, with exceptions such as South America in 2008, where distance, importer GDP, or logistics are most prominent. Additionally, exporter GDP has greater importance than distance in the Middle East in 2005. The explanation may lie in the geographical situation of countries that make up these areas, as well as their internal conditions.

The LPI variable for the entire sample of countries (last column of Table 1) presents significant and positive coefficients for the exporter and importer, with a greater importance of logistics for the former ( 0.369 compared to 0.284 of the importer in 2005 and 0.369 compared to 0.328 in 2008). However, when analysed by area, this result is not so open to generalisation. In Africa, South America (only in 2005), and the Middle East, importer logistics has greater importance in trade because of the condition of developing countries, while importers include both developed and emerging countries. Furthermore, it is observed that in only 3 years, all countries have demonstrated that their trade volume is more sensitive to the supply chain, with South America as a prominent example whose logistics have gone from having a coefficient of 0.208 to 0.546 , becoming the most relevant variable for export volume (behind only importer GDP). These results reveal efforts undertaken both by the private and public sectors in an attempt to progress internationally as a way of boosting country growth.

The Far East deserves a special mention because while in 2005 the relevance of exporter LPI was greater than the relevant measure for the importer, immediately behind importer GDP, in 2008, the situation changed in a radical way. The wealth of these countries became more relevant than other variables $\left(\beta_{2}=0.665\right)$, i.e., the economic development of the country significantly displaced concern for the more agile and improved external competitiveness of their products $\left(\beta_{6}=0.146\right)$. 
Regarding population, an interesting trend may be observed in Eastern Europe.

The exporter population coefficient in $2008\left(\beta_{4}=0.664\right)$ showed its decisive condition in trade volume, and conducted estimates reveal that the weight of this variable is as relevant as importer GDP, which is made up primarily by developed countries. Thus, these results show that the economies in question have still not perceived the need to optimise their distribution chains as a key element of their external relations. The rest of the coefficients corresponding to the dummy variables show the intrinsic, cultural, and historical characteristics of each area.

Following the purpose of this study, estimates of the gravity model where the LPI variable is substituted by one of its components were performed, as explained in the methodology. Listed below in Table 2 are the coefficients of these components, where each cell of the table refers to an estimate conducted on the equations $(3,4,5,6,7$, and $8)$.

Table 2. Coefficients of the components of LPI by geographical area

\begin{tabular}{|c|c|c|c|c|c|c|c|c|c|c|c|c|c|}
\hline & & \multicolumn{2}{|c|}{ Customs } & \multicolumn{2}{|c|}{ Infraestructure } & \multicolumn{2}{|c|}{$\begin{array}{c}\text { International } \\
\text { shipments }\end{array}$} & \multicolumn{2}{|c|}{$\begin{array}{c}\text { Logistic quality } \\
\text { competence }\end{array}$} & \multicolumn{2}{|c|}{$\begin{array}{l}\text { Tracking } \\
\text { tracking }\end{array}$} & \multicolumn{2}{|c|}{ Timeliness } \\
\hline & & 2005 & 08 & 005 & 2008 & 2005 & 2008 & 2005 & 2008 & 2005 & 2008 & 2005 & 2008 \\
\hline 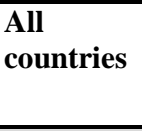 & DAp & $\begin{array}{l}0.312^{* * *} \\
0.248^{* * *}\end{array}$ & $\begin{array}{l}0.340^{* * *} \\
0.290^{* * *}\end{array}$ & $\begin{array}{l}398^{* * *} \\
311^{* * *} \\
\end{array}$ & $\begin{array}{l}0.337^{* * *} \\
0.362^{* * *}\end{array}$ & $\begin{array}{l}0.275^{* * *} \\
0.243^{* * *}\end{array}$ & $\begin{array}{l}0.270^{* * * *} \\
0.090^{* * *}\end{array}$ & $\begin{array}{l}0.308^{* * *} \\
0.234^{* * *}\end{array}$ & $\begin{array}{l}0.364^{* * *} \\
0.330^{* * *}\end{array}$ & $\begin{array}{l}0.323^{* * *} \\
0.221^{* * *}\end{array}$ & $\begin{array}{l}0.239^{* * *} \\
0.266^{* * *}\end{array}$ & $\begin{array}{l}0.317^{* * *} \\
0.144^{* * *}\end{array}$ & $\begin{array}{l}0.167^{* * *} \\
0.160^{* * *} \\
\end{array}$ \\
\hline & np & $455^{* * *}$ & $\begin{array}{l}0.216^{* * *} \\
0.389^{* * *}\end{array}$ & $\begin{array}{l}0.243^{* * *} \\
0.454^{* * *}\end{array}$ & $\begin{array}{l}0.203^{* * *} \\
0.423^{* * *}\end{array}$ & $\begin{array}{l}0.222^{* * *} \\
0.427^{* * *}\end{array}$ & $\begin{array}{c}0.249^{* * * *} \\
0.077^{*}\end{array}$ & $\begin{array}{l}0.136^{* * * *} \\
0.359^{* * *}\end{array}$ & $\begin{array}{l}0.267^{* * *} \\
0.358^{* * *}\end{array}$ & $\begin{array}{l}0.224^{* * *} \\
0.398^{* * *}\end{array}$ & $\begin{array}{l}0.277^{* * *} \\
0.273^{* * *}\end{array}$ & $\begin{array}{l}0.085^{* * *} \\
0.305^{* * *}\end{array}$ & $\begin{array}{l}0.099^{* * * *} \\
0.169^{* * *}\end{array}$ \\
\hline & $1 \mathrm{p}$ & & $\begin{array}{c}0.105^{*} \\
0.193^{* * *}\end{array}$ & & $0.217^{* * *}$ & $\begin{array}{l}-0.117^{* * *} \\
0.283^{* * *} \\
\end{array}$ & $\begin{array}{l}-0.092^{* * * *} \\
0.115^{* * *}\end{array}$ & $\begin{array}{c}-0.014 \\
0.188^{* * *} \\
\end{array}$ & $\begin{array}{c}0.083^{*} \\
0.239^{* * * *} \\
\end{array}$ & $\begin{array}{c}-0.01 \\
0.170^{* * *} \\
\end{array}$ & $\begin{array}{c}-0.026 \\
0.231^{\text {**** }} \\
\end{array}$ & $\begin{array}{c}0.011 \\
0.084^{* *} \\
\end{array}$ & $\begin{array}{c}0.031 \\
0.135^{* * *} \\
\end{array}$ \\
\hline $\begin{array}{l}\text { Ext } \\
\text { Ori }\end{array}$ & $\begin{array}{l}\text { Exp } \\
\text { Imp }\end{array}$ & $\begin{array}{l}86^{* * * *} \\
36^{* * *}\end{array}$ & $\begin{array}{l}0.251^{\text {****}} \\
0.316^{* * *}\end{array}$ & $\begin{array}{l}380^{* * * *} \\
324^{* * *}\end{array}$ & $\begin{array}{l}0.354^{* * * *} \\
0.397^{* * *}\end{array}$ & $\begin{array}{l}0.309^{* * *} \\
0.268^{* * *}\end{array}$ & $\begin{array}{c}0.029 \\
0.096^{* * *}\end{array}$ & $\begin{array}{l}0.322^{* * * *} \\
0.246^{* * *}\end{array}$ & $\begin{array}{l}0.163^{* * *} \\
0.332^{* * * *}\end{array}$ & $\begin{array}{l}0.373^{* * *} \\
0.247^{* * *}\end{array}$ & $\begin{array}{l}0.115^{* *} \\
0.263^{* * *}\end{array}$ & $\begin{array}{l}0.384^{* * *} \\
0.157^{* * *}\end{array}$ & $\begin{array}{c}-0.008 \\
0.228^{* * *}\end{array}$ \\
\hline $\begin{array}{l}\text { South } \\
\text { Americ }\end{array}$ & $\mathrm{xp}$ & $\begin{array}{l}0.105^{* * *} \\
0.186^{* * *} \\
\end{array}$ & $\begin{array}{l}0.427^{* * *} \\
0.331^{* * *}\end{array}$ & $\begin{array}{l}0.321^{\text {*** }} \\
0.216^{\text {*** }}\end{array}$ & $\begin{array}{l}0.779^{* * *} \\
0.405^{* * *}\end{array}$ & $\begin{array}{c}0.013 \\
0.211^{* * *} \\
\end{array}$ & $\begin{array}{c}-0.024 \\
0.158^{* * *} \\
\end{array}$ & $\begin{array}{l}0.350^{* * *} \\
0.200^{* * *} \\
\end{array}$ & $\begin{array}{l}0.577^{* * *} \\
0.408^{* * *}\end{array}$ & $\begin{array}{l}0.260^{* * *} \\
0.175^{* * *} \\
\end{array}$ & $\begin{array}{l}0.093^{* *} \\
0.355^{* * *}\end{array}$ & $\begin{array}{l}0.131^{* * *} \\
0.104^{* *} \\
\end{array}$ & $\begin{array}{l}0.347^{* * *} \\
0.189^{* * *} \\
\end{array}$ \\
\hline $\begin{array}{l}\text { Middle } \\
\text { East }\end{array}$ & $\mathrm{mp}$ & $\begin{array}{l}0.183^{* * *} \\
0.232^{* * *}\end{array}$ & $\begin{array}{l}0.201^{* * *} \\
0.301^{* * *}\end{array}$ & $\begin{array}{l}0.234^{* * *} \\
0.315^{* * *}\end{array}$ & $\begin{array}{l}0.301^{* * * *} \\
0.416^{* * *}\end{array}$ & $\begin{array}{l}0.179^{* * *} \\
0.195^{* * *}\end{array}$ & $\begin{array}{l}0.150^{* * * *} \\
0.122^{* * *}\end{array}$ & $\begin{array}{l}0.166^{* * *} \\
0.207^{* * *}\end{array}$ & $\begin{array}{l}0.141^{* * * *} \\
0.344^{* * *}\end{array}$ & $\begin{array}{l}0.187^{* * *} \\
0.171^{* * *}\end{array}$ & $\begin{array}{c}-0.036 \\
0.237^{* * *}\end{array}$ & $\begin{array}{l}0.209^{* * * *} \\
0.136^{* *}\end{array}$ & $\begin{array}{c}-0.222^{* * * *} \\
0.090^{* *}\end{array}$ \\
\hline
\end{tabular}

Dependent variable: Exportations

Note: $*, * *$ and $* * *$ denote test statistical significance at the $10 \%, 5 \%$ and $1 \%$ levels, respectively.

Source: Own elaboration 
Considering all countries between 2005 and 2008 and from the exporter perspective, only a slight improvement in Tracking and tracing, Customs and Competence is notable, while importers have improved in all components except for International shipments. The key variable for developing countries in 2005 was Infrastructure, while three years later it was overtaken by Competence, showing the increasingly strong concern for improving logistical services as a factor of increasing export.

By geographical area, no clear pattern can be deduced from the results. We see the efforts made in South America in Infrastructure, Customs, Competence, and Timeliness, to the detriment of important variables such as Tracking and tracing and International shipments, behaviour that is similar to the Middle East. The countries from the latter area have seen improvements in Customs and Infrastructure. Meanwhile, in Africa, Infrastructure has lost relevance. Lastly, Eastern Europe shows very residual concern for logistical issues as a way to improve its trade.

In any case, in both years and in general, the strong significance of various components in different areas in developing countries reinforces the global discourse on the importance of logistical performance. Specifically, the relevance of Infrastructure corresponds to policy and political impulse, which show positive results in international trade. In contrast, the actions of the private sector in International shipments, Competence, or Timeliness have much less importance.

Below, the results of the trade cost determinants are analysed with the OLS estimation of equation (9), facilitating the detection of variables in the different geographical areas that should see more effort to improve their international position and maximise their growth (Table 3). 
Table 3. Determinants of trade costs

\begin{tabular}{|c|c|c|c|c|c|c|c|c|c|c|c|c|}
\hline & \multicolumn{2}{|c|}{ Africa } & \multicolumn{2}{|c|}{ Eastern Europe } & \multicolumn{2}{|c|}{ Far East } & \multicolumn{2}{|c|}{ South America } & \multicolumn{2}{|c|}{ Middle East } & \multicolumn{2}{|c|}{ All countries } \\
\hline & 2005 & 2008 & 2005 & 2008 & 2005 & 2008 & 2005 & 2008 & 2005 & 2008 & 2005 & 2008 \\
\hline Distance & $0.063^{* * *}$ & $0.066^{* * *}$ & $0.141^{* * *}$ & $0.153^{* * *}$ & $0.078^{* * * *}$ & $0.075^{* * *}$ & $0.100^{* * * *}$ & $0.084^{* * *}$ & $0.084^{* * *}$ & $0.079^{* * * *}$ & $0.098^{* * *}$ & $0.100^{* * *}$ \\
\hline Tariff & $0.011^{* *}$ & $0.020^{* * *}$ & $0.010^{*}$ & 0.002 & $-0.016^{* * *}$ & $-0.023^{* * *}$ & $-0.008^{* *}$ & 0.007 & -0.006 & 0.012 & 0.001 & $0.016^{* * *}$ \\
\hline RTA & $-0.021^{* * * *}$ & $-0.030^{* * *}$ & $-0.011^{*}$ & -0.004 & 0.001 & -0.005 & $-0.030^{* * *}$ & $-0.033^{* * *}$ & $-0.018^{* * *}$ & -0.005 & $-0.014^{* * * *}$ & $-0.013^{* * *}$ \\
\hline contig & $-0.026^{* * *}$ & $-0.022^{* * *}$ & $-0.035^{* * *}$ & $0.038^{* * * *}$ & $-0.018^{* * *}$ & $-0.016^{* * *}$ & $-0.019^{* * *}$ & $-0.021^{* * *}$ & $-0.015^{* *}$ & $-0.015^{* *}$ & $-0.027^{* * *}$ & $-0.025^{* * * *}$ \\
\hline c.off & $-0.025^{* * *}$ & $-0.033^{* * *}$ & -0.002 & -0.005 & $-0.013^{*}$ & -0.006 & -0.003 & -0.009 & $-0.037^{* * *}$ & $-0.031^{* * *}$ & $-0.015^{* * *}$ & $-0.012^{* * *}$ \\
\hline c.ethno & -0.002 & 0.011 & -0.004 & -0.005 & 0.006 & 0.012 & $-0.027^{*}$ & $-0.034^{* *}$ & -0.005 & -0.005 & -0.004 & -0.001 \\
\hline colony & -0.018 & -0.013 & -0.005 & -0.004 & -0.005 & 0.000 & -0.007 & -0.001 & -0.010 & -0.007 & $-0.007^{* *}$ & $-0.007^{* *}$ \\
\hline comcol & $-0.020^{* * *}$ & $-0.014^{* * *}$ & $-0.052^{* * *}$ & $0.054^{* * *}$ & -0.002 & $-0.014^{* * *}$ & $-0.006^{*}$ & $0.011^{* * *}$ & -0.007 & $-0.012^{* *}$ & $-0.011^{* * *}$ & $-0.009^{* * *}$ \\
\hline col45 & -0.002 & -0.005 & $-0.029^{* * *}$ & $-0.024^{* *}$ & -0.010 & -0.016 & -0.005 & -0.004 & 0.010 & 0.007 & $-0.011^{* * *}$ & $-0.008^{* *}$ \\
\hline smetry & -0.005 & -0.001 & 0.004 & -0.003 & $-0.010^{* *}$ & -0.006 & $-0.01^{* *}$ & -0.007 & $0.013^{* *}$ & $0.015^{* * *}$ & $-0.005^{* *}$ & -0.002 \\
\hline LPI & $-0.062^{* * *}$ & $-0.041^{* * *}$ & $-0.065^{* * *}$ & $-0.091^{* * *}$ & $-0.171^{* * *}$ & $-0.138^{* * *}$ & $-0.101^{* * *}$ & $-0.101^{* * *}$ & $-0.068^{* * *}$ & $-0.077^{* * *}$ & $-0.109^{* * *}$ & $-0.090^{* * *}$ \\
\hline Entry cost & 0.003 & $0.009^{*}$ & $0.011^{* *}$ & $0.011^{\text {** }}$ & $-0.036^{* * *}$ & -0.008 & $0.016^{* * *}$ & -0.002 & 0.005 & 0.001 & $0.005^{* *}$ & $0.007^{* * *}$ \\
\hline Linear air & $-0.063^{* * *}$ & $-0.07^{* * *}$ & $-0.064^{* * *}$ & $-0.06^{* * *}$ & 0.000 & -0.006 & $-0.047^{* * *}$ & $-0.048^{* * *}$ & $-0.043^{* * *}$ & $-0.051^{* * *}$ & $-0.041^{* * * *}$ & $-0.052^{* * * *}$ \\
\hline Exchange rate & $0.010^{* *}$ & $0.024^{* * *}$ & $-0.016^{* * *}$ & $0.020^{* * * *}$ & -0.006 & $-0.018^{* * *}$ & $-0.012^{* * *}$ & $-0.013^{* * *}$ & -0.010 & -0.001 & $-0.013^{* * *}$ & $-0.008^{* * *}$ \\
\hline $\mathbf{R}^{2}$ & 0.423 & 0.450 & 0.717 & 0.728 & 0.500 & 0.437 & 0.600 & 0.583 & 0.467 & 0.483 & 0.532 & 0.512 \\
\hline
\end{tabular}

Dependent variable: Trade cost

Note: $*, * *$ and $* * *$ denote test statistical significance at the $10 \%, 5 \%$ and $1 \%$ levels, respectively.

Source: Own elaboration

The importance of factors explaining trade costs is mainly focused on public policy and export policies that enable their minimisation to improve the competitiveness of the countries. In the initial estimates conducted using a gravity equation, as specified by the literature, the distance variable has been understood as an indication of trade cost. However, it is well known that there are other factors apart from distance that condition trade cost.

First, in line with prior research (Arvis et al. 2013), the importance of distance and LPI as determinants of trade costs in the analysed years are noteworthy. The importance of trade facilitators in the development of countries is reinforced, in turn reinforcing the fact that improved logistics significantly reduces the cost of export in 
emerging areas. Furthermore, this result confirms the good practice of taking distance as a proxy of costs.

The results shown in Table 3 do not allow establishing a common model for all developing countries. In the Far East and South America, logistics is more relevant than distance as an explanatory variable, i.e., progress in distribution chains could have great repercussions in the reduction of cost. Variations in the study years do exist, but they are limited to slight oscillation.

As a whole, the explanatory variables for costs are significant and present signs coherent with economic theory. Specifically, tariffs and opening costs present positive signs because an increase in these variables would lead to general increases. In contrast, all qualitative dummy variables (language, colony, border, same country and trade agreement) together with air connectivity and exchange rate have negative signs because they are factors that favour trade, and their existence in common leads to cheaper export.

If every component of the LPI is analysed, using individual estimates and following the same structure as equation (9) but substituting LPI with each component, the following results are obtained (Table 4). 
Table 4. Coefficients of LPI components in the trade costs equation.

\begin{tabular}{|c|c|c|c|c|c|c|c|c|c|c|c|c|}
\hline & \multicolumn{2}{|c|}{ África } & \multicolumn{2}{|c|}{ Eastern Europe } & \multicolumn{2}{|c|}{ Far East } & \multicolumn{2}{|c|}{ South America } & \multicolumn{2}{|c|}{ Middle East } & \multicolumn{2}{|c|}{ All countries } \\
\hline & 2005 & 2008 & 2005 & 2008 & 2005 & 2008 & 2005 & 2008 & 2005 & 2008 & 2005 & 2008 \\
\hline Customs & $-0.053^{* * *}$ & $0.032^{* * *}$ & $-0.052^{* * *}$ & $0.081^{* * *}$ & $-0.153^{* * *}$ & $0.119^{* * *}$ & $-0.069^{* * *}$ & $0.070^{* * *}$ & $-0.058^{* * *}$ & $0.024^{* * *}$ & $-0.086^{* * *}$ & $0.066^{* * *}$ \\
\hline Infraestructure & $-0.071^{* * *}$ & $-0.040^{* * *}$ & $-0.066^{* * *}$ & $-0.091^{* * *}$ & $-0.166^{* * *}$ & $-0.151^{* * *}$ & $-0.097^{* * *}$ & $-0.098^{* * *}$ & $-0.066^{* * *}$ & $0.069^{* * *}$ & $-0.107^{* * *}$ & $0.088^{* * * *}$ \\
\hline $\begin{array}{l}\text { International } \\
\text { shipment }\end{array}$ & $-0.057^{* * *}$ & $-0.040^{* * *}$ & $-0.045^{* * * *}$ & $-0.061^{* * *}$ & $-0.140^{* * *}$ & $-0.077^{* * *}$ & $-0.078^{* * *}$ & $-0.037^{* * *}$ & $-0.056^{* * *}$ & $-0.055^{* * *}$ & $-0.091^{* * *}$ & $-0.051^{* * *}$ \\
\hline $\begin{array}{l}\text { Logistic quality } \\
\text { competence }\end{array}$ & $-0.045^{* * *}$ & $-0.043^{* * *}$ & $-0.063^{* * * *}$ & $-0.101^{* * *}$ & $-0.157^{* * *}$ & $-0.138^{* * *}$ & $-0.105^{* * *}$ & $-0.104^{* * *}$ & $-0.062^{* * *}$ & $0.080^{* * *}$ & $-0.099^{* * *}$ & $0.097^{* * *}$ \\
\hline $\begin{array}{l}\text { Tracking } \\
\text { tracing }\end{array}$ & $-0.042^{* * *}$ & $0.028^{* * *}$ & $-0.046^{* * * *}$ & $-0.083^{* * *}$ & $-0.157^{* * *}$ & $-0.116^{* * *}$ & $-0.091^{* * *}$ & $-0.082^{* * *}$ & $-0.066^{* * *}$ & $0.067^{* * *}$ & $-0.095^{* * *}$ & $0.073^{* * *}$ \\
\hline Timeliness & $-0.033^{* * *}$ & $-0.032^{* * *}$ & $-0.063^{* * *}$ & $-0.064^{* * *}$ & $-0.143^{* * *}$ & $-0.114^{* * *}$ & $-0.073^{* * *}$ & $-0.079^{* * *}$ & $-0.039^{* * *}$ & $-0.056^{* * *}$ & $-0.087^{* * *}$ & $0.072^{* * *}$ \\
\hline
\end{tabular}

Dependent variable: Trade cost

Note: $* * *$ and $* * *$ denote test statistical significance at the $10 \%, 5 \%$ and $1 \%$ levels, respectively.

Source: Own elaboration

At the component level, the most important determining factor is Infrastructure in 2005 and International shipments in 2008. There is a behaviour change, indicating that public policy has less importance than private sector spheres, and anticipation and reaction to market change is better.

\section{Conclusions}

Export is directly conditioned by the cost paid, which in turn is conditioned by the logistical level of a country. Focusing on this premise, in the paper, the importance of specific explanatory variables of trade facilitators for export volume and their importance in trade costs have been analysed. All this analysis was performed to provide empirical evidence on which logistical dimensions should be treated with priority.

Various gravity equations have been examined to detect which logistical variables have greater influence on trade in developing countries. This question is key 
for these areas, as some countries have a limited capacity for growing possible external relations with other countries. Furthermore, following specifications found in the literature, an explanatory equation of trade costs was used to establish how these factors could be optimised for these areas to gain competitiveness.

The results show that the analysed countries should continue to rely on improving their logistical infrastructure not only to improve their trade but also to improve their competitiveness. Other variables that are an important conditioning factor of trade cost, including traceability, should be developed with greater intensity because even though they are significant in determining trade, they have not had decisive importance given to them in the analysed years.

Trade facilitator in Eastern Europe are a pending subject, as logistics has not been significant in determining exportation but has vital importance regarding the magnitude of their costs.

Ultimately, it can be concluded that in no case is it possible to establish a common pattern for all developing areas, as their economic, cultural, and political characteristics are very different. The results reflect the aspects that should be reinforced to improve these countries' international positioning. 


\section{References}

Anderson, J. and van Wincoop E. (2003) Gravity with gravitas: A solution to the border puzzle. American Economic Review 93 (1): 170-192.

Anderson, J.E. (1979) A theoretical foundation to the gravity equation. American Economic Review 69 (1): 106-116.

Arvis, J.F., Duval, Y., Shepherd, B. and Utoktham, C. (2013) Trade Costs in the Developing World 1995-2010. The World Bank. Poverty Reduction and Economic Management Network. International Trade Department no 6309.

Arvis, J.F., Mustra, M., Ojala, L., Shepherd, B. and Saslavsky, D. (2007) Connecting to Compete: Trade logistics in the global economy. Washington: World Bank.

Arvis, J.F., Mustra, M., Ojala, L., Shepherd, B. and Saslavsky, D. (2012) Connecting to Compete: Trade logistics in the global economy. Washington: World Bank.

Arvis, J.F., Mustra, M., Panzer, J., Ojala, L. and Naula, T. (2010) Connecting to Compete: Trade logistics in the global Economy. Washington: World Bank.

Behar, A. and Manner, P. (2008) Logistics and Exports. African Economics Working Paper Series 293.

Bensassi, S., Martinez-Zarzoso, I., Suarez, C. (2015) The effect of maritime transport costs on the extensive and intensive margins: evidence from the Europe-Asia Trade. Maritime Economics and logistic, 16: 276-297.

Bergstrand, J.H. (1985) The gravity equation in international trade: Some microeconomic foundations and empirical evidence. The Review of Economics and Statistics 67 (3): 474-481.

Bergstrand, J.H. (1989) The generalized gravity equation, monopolistic competition, and the factor-proportions theory in international trade. The Review of Economics and Statistics 71 (1): 143-153.

Chen, N. and Novy, D. (2011) Gravity, Trade Integration, and heterogeneity across industries. Journal of International Economics 85 (2): 206-221. doi:10.1016/j.jinteco.2011.07.005

Clark, X., Dollar, D. and Micco, A. (2004) Port efficiency, maritime transport cost, and bilateral trade. Journal of Development Economics 75 (2): 417-450.

Deardoff, A.V. (1995) Determinants of bilateral trade: does gravity work in a neoclassic world?. National Bureau of Economic Research Working Paper 5377.

Decreux, I. and Fontagne, L. (2006) A quantitative assessment of the outcome of the Doha development agenda. CEPII working paper 2006-10.

Dennis, A. (2006) The impact of regional trade agreements and trade facilitation in the Middle East and North Africa region. World Bank Policy Research Working Paper 3837.

Duval, Y. and Utoktham, C. (2011) Intraregional trade cost in Asia: A Primer. AsiaPacific Development Journal 18 (2): 1-23

Evenett, S. and Keller, W. (1998) On theories explaining the success of the gravity equation. National Bureau of Economic Research, Working Paper 6529. 
Heckman, J. (1979) Sample selection bias as a specification error. Econometrica 47 (1): 153-161.

Helpman, E. and Krugman, P. (1985) Market structure and foreign trade. Increasing returns, imperfect competition and the international economy. London: The MIT Press.

Henderson, J.V., Shalizi, Z. and Venables A.J. (2001) Geography and development. Journal of Economic Geography 1 (1): 81-106.

Hoekman, B and Nicita, A. (2011) Trade Policy, trade costs, and developing country trade. World Development 39: 2069-2079.

Korinek, J and Sourdin, P. (2011) To what extent are high-quality logistics services trade facilitating?. OECD Trade Policy Working Papers 108. OECD Publishing.

Krugman, P. (1991) Increasing returns and economic geography. Journal of Political Economy 99 (3): 483-499.

Limao, N and Venables, A.J. (2001) Infrastructure, geographical disadvantage, transport costs and trade. The World Bank Economic Review 15 (3): 451-479.

Martinez-Zarzoso, I., García-Menendez L. and Suarez-Burguet C. (2003) Impact of transport costs on international trade: The case of Spanish ceramic exports. Maritime Economics \& Logistics 5: 179-198.

Martinez-Zarzoso, I., Perez-García E. and Suarez-Burguet, C. (2008) Do transport cost have a differential effect on trade and the sectoral level?. Applied Economics 40 (24): 3145-3157.

Martínez, V., Bengoa, M. and Sánchez-Robles, B. (2012) Unión Europea e integración comercial: ¿Resulta relevante el efecto frontera?. Revista de Economía Mundial 32: $175-188$.

Moïsé, E. and Sorescu, S. (2013) Trade Facilitation Indicators: The potential impact of trade facilitation on developing countries' Trade. Paris: OECD Trade Policy Papers, no. 144.

Miroudot, S., Saurage, J. and Shepherd, B. (2012) Measuring the cost of international trade in services. WIOD Conference, Vienna, 26-28 May 2010.

Novy, D. (2013) Gravity redux: Measuring international trade cost with panel data. Economic Inquiry 51: 101-121.

Persson, M. (2013) Trade facilitation and the extensive margin. The Journal of International Trade \& Economic Development 22 (5): 658-693.

Pöyhönen, P. (1963a) A tentative model for the volume of trade between countries. WeltwirschaftlichesArchiv 90: 93-99.

Pöyhönen, P. (1963b) Toward a general theory of international trade. Ekonomiska Samfundets Tidskrift 16: 69-78.

Tinbergen, J. (1962) Shaping the world Economy: suggestions for international economic policy. New York: The Twentieth Century, Inc.

Wilmsmeier, G., Hoffmann, J, and Sanchez R. J. (2006) The impact of port characteristics on international maritime transport cost. Research in transportation economics 16: 117-140. 